\title{
Role of Components Containing in Water on the Formation Corrosion - scale Deposits in Pipelines of Heating Systems
}

\author{
N.A. VYSOTSKAYA, B. KABYLBEKOVA, A.ANARBAYEV, \\ A. TUKIBAYEVA* and G. ADYRBEKOVA
}

M.Auezov South Kazakstan State University Department of "Chemistry", M.Auezov South Kazakhstan State University, 5 Tauke-khan ave., Shymkent, 160000, Kazakhstan.

${ }^{\star}$ Corresponding author E-mail: ainur_tukibaeva@mail.ru

http://dx.doi.org/10.13005/ojc/320128

(Received: November 18, 2015; Accepted: March 04, 2016)

\section{ABSTRACT}

In this paper, we propose results of research on the establishment of presence of components in water of the southern cities of the Republic of Kazakhstan such as carbonate hardness, noncarbonate hardness and total hardness, content of free carbonic acid and impurities of different ions of iron (two- and three-valent), sulphate and chlorine ions, $\mathrm{pH}$ value. When the research course parameters of heat carrier (water): carbonate hardness, non-carbonate hardness, and the total hardness, content of free carbonic acid ions and $\mathrm{HCO}_{3}^{-}, \mathrm{pH}$ value, content of two and three valence iron ions, sulphate and chloride-ions in water were established, indicators of corrosion were calculatedby the value, which we concluded about the strength of corrosive effect on steel foundation of pipelines.

Key words: Corrosion Scale Deposits, Corrosion Rate, Water Hardness.

\section{INTRODUCTION}

The efficiency of heating of residential, public and industrial facilities with heat depends on the cleanliness of the inner surface of pipelines.

Water with temperatures of $120-150^{\circ} \mathrm{C}$ is aheat carrier in district heating systems, including heat sources, heating networks and heat consuming installation ${ }^{1}$.In such modes corrosion scale deposits are accumulated on the inner surface of the thermal systems that sharply reduce their capacity, most importantly - heat transfer from the surfaces of the heating batteries and other heating appliances and blocks. Maintenance of heating systems in a clean condition without corrosion can be achieved by chemical cleaning of heating systems from corrosion scale deposits.

In order to remove the corrosion - scale deposits from inner surface of pipelines in heating systems is necessary to select effective, cheap 
washings with low corrosive activity of not more than $0.05 \mathrm{~mm} /$ year $^{2}$.

Fresh water is a heat carrier, with a content of soluble calcium and magnesium salts, causes appearance of corrosion - scale deposits when their concentrations in the form of ions in the range 3-11 $\mathrm{mEq} / \mathrm{L}$ in water and selection of the washing solutions will directly depend on the water hardness, contributing certain undesirable accumulation of corrosion - scale deposits of different nature and composition, the content of free carbonic acid in the form of $\mathrm{CO}_{2}, \mathrm{HCO}_{3}^{-}, \mathrm{SO}_{3}{ }^{2-}$, ferric ions, total iron, chloride - ions and sulphate - ions.
The authors of the work ${ }^{3}$ investigated the physical and chemical characteristics of water of sebkha of Oran ponds. In an attempt to study the environmental impact on water quality, fifty samples were collected and analyzed. The salinization is the main source of the pollution in this basin. It was established that majority of the groundwater samples irrespective of seasons fall in field of the 6 , which indicates that the groundwater samples have permanent hardness and does not deposit residual sodium carbonate in irrigation use.

In work ${ }^{4}$ presented the results of study physico-chemical parameters of water of Seevanriver

Table 1: Indicators of carbonate, non-carbonate andt otal hardness of water in various cities of South Kazakhstan region (Kazakhstan)

\begin{tabular}{lcccccc}
\hline City & $\begin{array}{c}\text { The volume of } \\
\text { acid solution, } \mathrm{ml}\end{array}$ & $\begin{array}{c}\text { Normal concentration } \\
\text { of an acid }\end{array}$ & $\begin{array}{c}\text { The volume of } \\
\text { test sample }\end{array}$ & Hard $_{\text {carb }}$ & Hard $_{\text {total }}$ & Hard $_{\text {non-carb }}$ \\
\hline Shymkent & 6,8 & 0,05 & 100 & 3,4 & 4,7 & 1,37 \\
Arys & 8,8 & 0,05 & 100 & 4,4 & 5,1 & 0,8 \\
Lenger & 9,8 & 0,05 & 100 & 4,85 & 5,6 & 0,75 \\
Kentau & 18,2 & 0,05 & 100 & 9,1 & 9,55 & 0,45 \\
Turkestan & 18,3 & 0,05 & 100 & 9,15 & 9,9 & 0.7 \\
Saryagash & 16,6 & 0.05 & 100 & 8,3 & 8,85 & 0.55 \\
Shardara & 10,55 & 0.05 & 100 & 5,25 & 6,3 & 1.0 \\
\hline
\end{tabular}

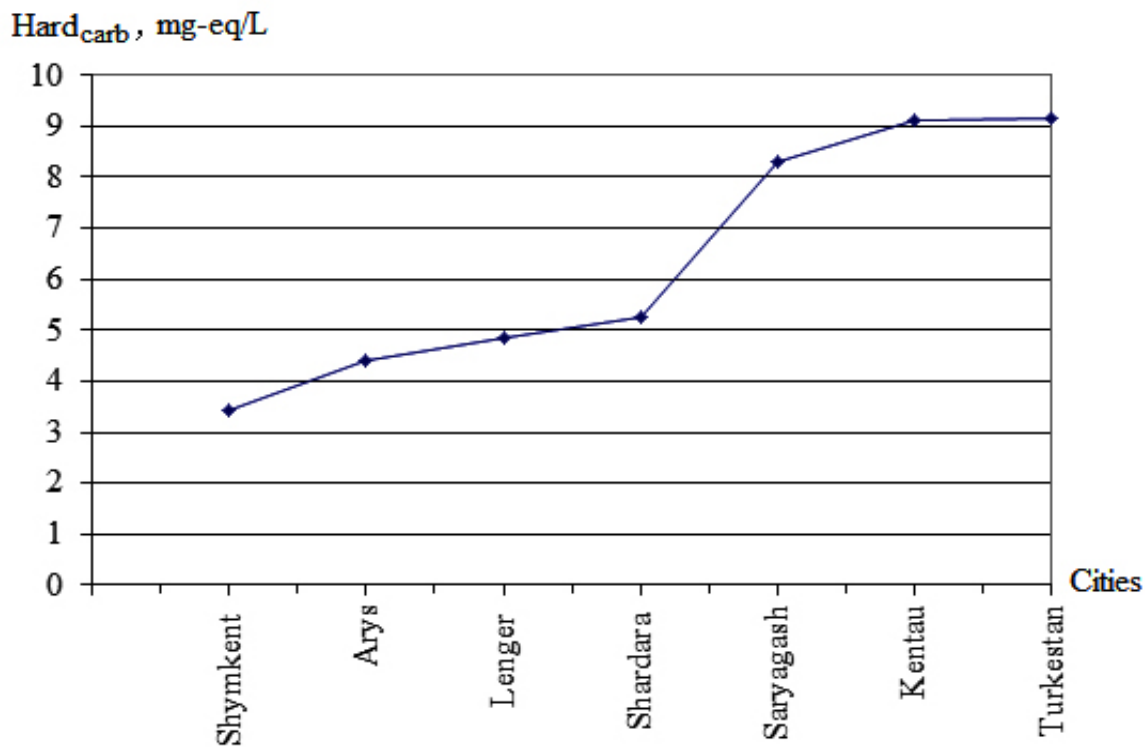

Fig. 1: The dependence of hardness of water by cities 
during 2009 in different seasons. As a result of study it was established that temperature influences the biologicalreactions in water. Its rise accelerates the chemicalreactions in water and also reduces solubility ofgases and D.O. (Dissolved Oxygen). Total hardness in caused by divalentcations. Hardness is found higher in monsoon. High values of nitrates are dueto domestic sewage and lotianallah. Phosphate hasranged of $0.72-1.4$ are found from 0.008 -0.024 and $0.04-0.59 \mathrm{ppm}$ respectively in this study. Chloride concentration increases due to theincrease of mineral content. Iron is present in thesoluble from in soil. WHO recommends the ironrange of 0.3 $\mathrm{mg} / \mathrm{L}$.

It is known that the aggressive properties of water are strongly depending on the hardness of water ${ }^{5}$. Water with a high carbonate hardness, where there is a positive index of saturation ${ }^{6}$, as a rule, it is non-aggressive, but promotes the deposition of corrosion-scale deposits, a soft water with a negative index of saturation does not form a substantial scale deposits, but it differs by the raised corrosiveness.

The composition of water of some southern cities in Kazakhstan for the registration of all types of hardness and other impurities in water was investigated.

\section{MATERIAL AND METHODS}

Water of cities of Shymkent, Arys, Shardara, Saryagash, Kentau, Lenger, Turkestan was selected for research.

In order to determine water hardness value, the known methods of titration by the solution of 1 $\mathrm{n}$ of hydrochloric $\mathrm{acid}^{7}$ in the presence of a methyl orange indicator until changing of its color.

The $\mathrm{pH}$ value of water was determined by a visual calorimetry using acid-base indicators (malachite green), using alkali solution ( $1 \mathrm{~N})$ and by means of $\mathrm{pH}$ meter and an ionomer.

Free carbonic acid was determined by quantitative transfer of carbon dioxide into $\mathrm{HCO}_{3}$ ions when the titration of the sample with alkali up to $\mathrm{pH}=8.4-8.6$ in presence of phenolphthalein indicator ${ }^{8}$.

The presence of free carbonic acid in water of studied cities was determined for more complete results. Divalent iron ions was determined using of ammonium sulphate $\left(\mathrm{NH}_{4}\right)_{2} \mathrm{~S}_{2} \mathrm{O}_{8}$ and hydrochloric acid by boiling. The total iron content in water, according to the regulations of Sanitary rules and norms should not exceed $3 \mathrm{mg} / \mathrm{L}^{9}$.

\section{Corrosion rate, $\mathrm{mm}$ /year}

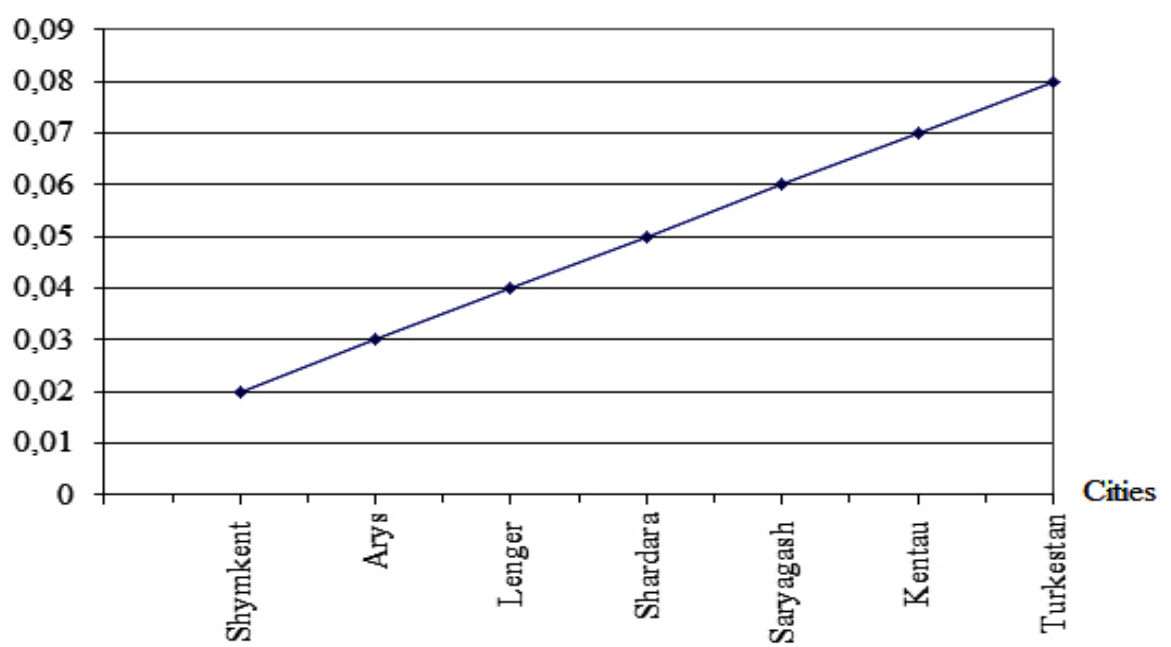

Fig. 2: Dependence of the corrosion rate of the steel sample in water of various cities 
Qualitative reactions on the content of $\mathrm{Fe}^{2+}$ ions in water were carried out by exchange and redox reactions ${ }^{10}$.

Water sample are put into the conical flasks, a few drops of sulphuric acid solution and a few drops of the solutions of potassium dichromate or potassium permanganate are added into the flask was and a slight change of orange color of potassium dichromate into a weakly green, which is characteristic for $\mathrm{Cr}^{3+}$, also weakening purple color of potassium permanganate, which is characteristic for $\mathrm{Mn}^{2+}$ are observed by reactions:

$$
\begin{aligned}
& 6 \mathrm{Fe}^{2+}+\mathrm{CrO}_{7}^{2-}+14 \mathrm{H}^{+}=6 \mathrm{Fe}^{3+}+2 \mathrm{Cr}^{3+}+7 \mathrm{H}_{2} \mathrm{O}^{-} \\
& 5 \mathrm{Fe}^{2+}+\mathrm{MnO}_{4}^{-}+8 \mathrm{H}^{+}=5 \mathrm{Fe}^{3+}+\mathrm{Mn}^{2+}+4 \mathrm{H}_{2} \mathrm{O}(2)
\end{aligned}
$$

Trivalent iron ions were determined using the solution of ammonia and sodium carbonate solution according to the reactions:

$$
\begin{aligned}
& \mathrm{Fe}^{3+}+3 \mathrm{NH}_{3}-\mathrm{H}_{2} \mathrm{O}=\mathrm{Fe}(\mathrm{OH})_{3}+3 \mathrm{NH}_{4}{ }^{+} \\
& 2 \mathrm{Fe}^{3+}+3 \mathrm{CO}^{2}{ }_{3}+3 \mathrm{H}_{2} \mathrm{O}=2 \mathrm{Fe}(\mathrm{OH})_{3}+3 \mathrm{CO}_{2}
\end{aligned}
$$

Determination of sulphate and chloride ions were carried out using the solutions of lead nitrate and silver nitrate according to the reactions:

$$
\begin{aligned}
& \mathrm{H}_{2} \mathrm{O}\left(\mathrm{So}_{4}^{2}\right)+\mathrm{Pb}\left(\mathrm{NO}_{3}\right)_{2}=\mathrm{PbSO}_{4} \downarrow \mathrm{No}_{3}^{-} \\
& \mathrm{H}_{2} \mathrm{O}(\mathrm{Cl}-)+\mathrm{AgNO}_{3}=\mathrm{AgCl} \downarrow+\mathrm{NO}_{3}^{-}
\end{aligned}
$$

\section{RESULT AND DISCUSSION}

Table 1 shows the indicators of all types of hardness in water of some southern cities of Kazakhstan.

The table shows that the water of Shymkent city has the greatest value of non-carbonate hardness (1.37 mEq/l) and Kentau - the lowest (0.45 $\mathrm{mEq} / \mathrm{L}$ ) and carbonate hardness values have inverse dependence: the greatest value is in Turkestan and Kentau, and the lowest is in water of Shymkent.

By such parameters we can assume that non-carbonate hardness is slightly, but promotes a precipitation of carbonate films of magnesium or calcium on the surface of pipe. The deposition of such film also depends on the concentration of free $\mathrm{CO}_{2}$ in water. It is known that in aqueous solutions, there is a balance between the various forms of carbonic acid:

$$
\begin{gathered}
\mathrm{H}_{2} \mathrm{CO}_{3} \leftrightarrow \mathrm{H}^{+}+\mathrm{HCO}_{3}^{-} \\
\mathrm{HCO}_{3}^{-} \leftrightarrow \mathrm{CO}_{3}^{-}+\mathrm{CO}_{2}+\mathrm{H}_{2} \mathrm{O}
\end{gathered}
$$

The ratio between the different forms $\left(\mathrm{HCO}_{3}^{-}, \mathrm{CO}_{3}^{-2}, \mathrm{CO}_{2}\right)$ also depends on the $\mathrm{pH}$ value. If the $\mathrm{pH}$ value is in the range of $3.7-4^{11}$, the whole carbonic acid in water are in the form of $\mathrm{CO}_{2}$ and with an increase of $\mathrm{pH}$ the proportion of $\mathrm{CO}_{2}$ decreases, and the proportion of $\mathrm{HCO}_{3}$-increases. When $\mathrm{pH}=$ 8-8.2 practically all present carbonic acid in water is in the form of bicarbonate ions.

Table 2: Indicators of the corrosion rate of iron in water for the cities of the South Kazakhstan region

\begin{tabular}{lcccc}
\hline City & $\begin{array}{c}\text { Corrosion rate, } \\
\text { mm/year }\end{array}$ & $\begin{array}{c}\text { Corrosion rate, Corrosion rate, } \\
\text { mg/m2•hour }\end{array}$ & $\begin{array}{c}\text { Corrosion rate, } \\
\text { mg/dm2•hour } \\
\text { mg/0,8dm2•hour }\end{array}$ \\
\hline Turkestan & 0,08 & 69 & 0,69 & 0,61 \\
Kentau & 0,07 & 63 & 0,63 & 0,50 \\
Saryagash & 0,06 & 54 & 0,54 & 0,43 \\
Shardara & 0,05 & 45 & 0,45 & 0.36 \\
Lenger & 0,04 & 36 & 0,36 & 0.29 \\
Arys & 0,03 & 27 & 0,27 & 0,22 \\
Shymkent & 0,02 & 9 & 0,09 & 0,072 \\
\hline
\end{tabular}


With further increase of $\mathrm{pH}>8.4$, the free $\mathrm{CO}_{2}$ in water can not exist, the proportion of carbonate ions $\mathrm{CO}_{3}^{-2}$ begins to rise in water, and the proportion of $\mathrm{HCO}_{3}^{-}$ions decrease, and when $\mathrm{pH}=$ 12 , all the carbon dioxide in water is in the form of ions $\mathrm{CO}_{3}^{-2}$.

The measured averaged indices of $\mathrm{pH}$ of water by cities are the following indicators:Shymkent city is 7.67; Lenger city is 7,035; Arys city is 7.47; Saryagash city is 7.96 ; Turkestan city is 6.63 .

The $\mathrm{pH}$ value for the mentioned cities have almost the same order, the $\mathrm{pH}$ value of water of Turkestan city is slightly lower.

Based on the obtained $\mathrm{pH}$ values we can conclude that in waters of studied cities an average value of $\mathrm{pH}$ is 7.5. Therefore, in these waters $\mathrm{HCO}_{3}^{-}$ ions are dominated and to expect strong carbonate deposits on the inner surfaces of pipes is not necessary.

Proceeding of redox reactions is associated with color change of the solution that allows to draw conclusions about the presence of iron ions in water.

Green color of solution of water, resulting from the redox reaction, wherein potassium dichromate acts as oxidizing agent (1), the disappearance of the purple color of the solution of potassium permanganate, where the latter acted as an oxidizer (2), once again proves the presence of iron ions $\left(\mathrm{Fe}^{2+}\right)$ in water.

In redox reactions for registration of trivalent iron - ion with ammonia solution (3) in water, water become reddish-brown hue, slight cloudiness of water and release of bubbles of carbon dioxide with sodium carbonate solution (4) also indicates the presence of ions $\mathrm{Fe} 3+$ in water:

After the spent qualitative reactions on twoand trivalent iron - ions we can say that in all of the analyzed water samples iron -ions are present.

Chemical analysis on the content of sulphate ions, which content of it in water is not officially regulated, showed the presence of it in the range of $40-90 \mathrm{mg} / \mathrm{l}$ in water of various cities. Turbidity of water and a white precipitate by reaction (5) indicates the presence of sulphate - ions.

Clouding of the solution of water with silver nitrate by reaction of (6) is explained by the formation of a white precipitate of silver chloride, obtained by binding of chloride ions present in water, with silver ions.

Chemical analysis showed that the average value of the content of chloride-ions in water samples of various cities is $170-230 \mathrm{mg} / \mathrm{l}$, which corresponds to the middle aggressiveness.

Using the data of measured and calculated indicators of water hardness, $\mathrm{pH}$ value, the presence of impurities, the samples of steel pipes of used in heat supply systems were tested for influence on them water intakes from different southern cities.

The experiment consisted in the fact that the weight of iron, passed into solution was determined in water of flow regime, based on the data the dependence of the corrosion rate from the composition of water in various cities was plotted.

The calculated values of the corrosion rate in water of various cities are shown in Table 2.

The table shows that the smallest value of corrosion rate is observed in water of Shymkent city (0.02) and the increase is directed towards to Saryagash (0.06), Kentau (0.07) Turkestan cities (0.08). Figure 2 shows the dependence of the corrosion rate of the steel sample in water of various cities.

Based on the obtained data we can say with certainty that the water of Shymkent, Aris, Lenger cities cause minor corrosion rate $(0.02-0.04 \mathrm{~mm} /$ year), water of Turkestan and Kentau cities cause significant corrosion rate (0.06-0.08 $\mathrm{mm} /$ year).

\section{CONCLUSION}

Based on the research of components of the water of some southern cities of the Republic of 
Kazakhstan influencing on the formation of corrosionscale deposits in the internal surface of the tube, we can make the following conclusions:

The parameters of iron - ions in water were established, which the quantitative content allows to the right approach for the choice of the inhibitor in washing process of heating systems. The set value of the $\mathrm{pH}$ value of water, allows to assume the presence of a small amount of $\mathrm{CO}_{2}$ and $\mathrm{SO}_{3}{ }^{2-}$ in
water.By the calculated parameters of corrosion rate it is possible an effective choice of the composition of solutions for flushing of heating systems. The installed components of water will greatly facilitate the selection of the composition of the flushing solutions for the removal of corrosion-scale deposits. The obtained data allow to select an inhibitor for creation of protective films on the inner surface of pipes for prevent their destruction.

\section{REFERENCES}

1. Volkov B.G., Tesov N.I., Shuvanov V.V. A reference book on corrosion protection of metal constructions. - St. Petersburg: Nedra, 2007, 223

2. Akolzin P.A., Preventing corrosion of technical equipment of water- and heat supply. Moscow, Metallurgy, (1988)

3. Boualla Nabila, Orien. J. Chem.,2014, 30, 3, 1125-1132

4. KatariaH.C.;Shalini Sharma, Orien. J.Chem.,2010, 26(1),337-338

5. Sholts F., Electroanalytical methods: theory and practice. Moscow, 2009, 326.

6. Rosenfeld I.L. Corrosion inhibitors. Moscow,
Chemistry, 1987, 349

7. Vysotskaya N.A., Satayev M.S., Dzholdasova Sh. Laboratory workshop on corrosion and protection of metals. Shymkent, 2009, 78

8. OST30-70-953.21-91. Methods for determinationof freecarbonic acid.Moscow, 1994.

9. Stozhko, N.Y.;Inzhevatova, O.V.;Golovin, L.I. J. Anal. Chem., 2005, 60, 7, 747-752

10. Lidin R.A. Tasks by general and inorganic chemistry. Moscow, Vlados, 2004,383

11. Akolzin A.P., Zhukov A.P. Oxygen corrosion of the equipment of chemical production. Mosow, Chemistry, 1985, 240 